\title{
O ESTADO DE EXCEÇÃO E O ESTADO DE GRAÇA
}

\section{THE STATE OF EXCEPTION AND THE STATE OF GRACE}

Raquel Wandelli Loth ${ }^{1}$

DOI 10.26512/aguaviva.v3i3.16895

Recebido em: 18 jul. 2018

Aceito em: 09 out. 2018

RESUMO: Analisada como máquina de guerra e de esgarçamento dos limites da linguagem, a literatura do devir (Deleuze) inventa estratégias para vingar uma língua da resistência do inumano (Lyotard). Com a invenção de uma pronominalidade neutra em Água viva (o it) e em Paixão Segundo G.H. (a massa branca da barata), Clarice Lispector cava na literatura dispositivos menores, capazes de potencializar uma sintaxe animal na escritura e libertar-se do modo frásico onde se estabelece a Ideia antropocêntrica.

Palavras-chave: Máquina de guerra; Máquina antropocêntrica; Clarice Lispector; Inumano; Língua da resistência.

ABSTRACT: Analyzed as war machine and overcoming the language's limits, the literature of becoming (Deleuze) creates strategies to avenge a language of inhuman resistence (Lyotard). With the invention of a neutral pronominalization in Água viva (the it) and in Passion According to G.H. (the cockroach's white mass), Clarice Lispector digs in the literature smallers devices, capable to potentialize an animal syntax in the writing and get free of the phrasing mode in which the anthropocentric idea is established.

Keywords: War machine; Anthropocentric machine; Clarice Lispector; Inhuman; Language of resistance.

Há dias que são tão áridos e desérticos que eu daria anos de minha vida em troca de uns minutos de graça.

(Clarice Lispector, 2004)

\footnotetext{
${ }^{1}$ Doutora em Literatura Brasileira pelo Programa de Pós Graduação em Literatura da Universidade Federal de Santa Catarina (UFSC/Capes) com a tese intitulada: Ver, pensar e escrever (como) um animal. Professora do Curso de Jornalismo da Universidade do Sul de Santa Catarina (Unisul).E-mail: raquelwandelli@gmail.com.
} 
Uma mensagem perdida, informe, desterritorializada entre o não-tempo da literatura e o datado do jornalismo, larga pelo caminho um fragmento desconexo do texto que a antecede: "P.S. Estou solidária, de corpo e alma, com a tragédia dos estudantes do Brasil". O recado póstumo ao final da crônica "Estado de graça (Trecho)", assinada por Clarice Lispector (2004, p. 118) e publicada no Jornal do Brasil, em 6 de abril de 1968, precisava chegar do exterior às multidões que carregavam o corpo do menino Edson Luís nas ruas do Rio de Janeiro. Aparentemente descontextualizado, separado do todo, fraturando, minando o tempo da diegese, a passagem do calabouço despista a sua própria localização, pois o trecho que se disfarça como um corpo intruso na máquina da escrita pode ser o território todo.

Contra o poder da linha dura, a escrita-cigana dissimula suas formas e conteúdos, largando pelos caminhos pegadas-fantasmas, intempestivas porque podem sempre ser recuperadas pelo corpo ferido das multidões, como um epílogo que continua. É o confronto entre a "graça de viver", tão rara para os homens, tão própria do animal, e o estado de exceção, tão atual e tão próprio do homem. Ausentando o centro, a máquina da escrita e da leitura opera para que o aparelho não saiba ao certo que trecho pertence ao outro, ou qual é a parte e qual é o todo, qual é a dobra e qual é a obra. Aí está o segredo que o guerreiro nômade aprendeu com o guerreiro-Xamã: ele desloca sem cessar o corpo da máquina para que o Estado não lhe aparelhe a alma.

Uma escritora-xamã passeia pelo território livre da poesia falando da graça de viver. Procurando-a por toda a parte, passeia pela inspiração, pela leveza da infância, pela lucidez dos sábios, pela beleza inatingível, pela vida selvagem. O texto-ser não teme em se contradizer e se reentretecer e se refazer. Ele bordeja a graça resistente a todas as definições, incapturável pela razão, pelos sentidos de véspera ou pela alegria do hábito. Não a encontra em tempos de aridez, justamente quando a graça de existir é mais necessária para contrapor ao deserto uma "espécie de confiança no sofrimento e em seus caminhos intoleráveis" (LISPECTOR, 2004, p. 117). O que é a graça? Ternura fluida e fugidia, mistério que não se explica, êxtase em calmaria, pura busca textual, anunciação. Esplendor da irradiação imanente das coisas, das pessoas, dos animais; "felicidade do vivo" que arrebata o ser quando ele menos espera, "suspiro de quem teve o mundo como este é", saudade do estado de quem experimentou "ganhar um corpo e uma alma e a terra".

A graça não dá seu endereço: não mora no ópio, nem nas religiões, não para em nenhum lugar, não advém da caridade ou do egoísmo. Não pertence a ninguém, nem ao homem. "Não 
sei por quê, mas acho que os animais entram com mais frequência na graça de existir do que os humanos" (LISPECTOR, 2004, p. 117). Ao estado de graça, espontâneo, imprevisível, se contrapõe o estado de exceção inequívoco, irrevogável do post-scriptum na definitude do asfalto onde jaz o menino, exigindo o lamento e a espada firme do guerreiro. Um corpo sem vida no meio do povo é verdade que não se divide, é tragédia que conclama a entrega toda do guerreiro - de "corpo e alma"2. Não é a pessoa da autora que se manifesta; esta há muito se ausentou no espaço literário. É o guerreiro nômade da escritura que dribla a máquina da censura para se fazer ouvir pelos povos que morrem.

Porque nenhum poder se estabelece sem instaurar imediatamente um contra poder, como nos ensinou Foucault (2010), toda máquina de dominação carrega o germe da sua destruição. Nessa perspectiva Deleuze e Guattari trazem para o campo do político e do estético o conceito de máquina de guerra. O que essa ideia produz como resultado é a propagação da própria ideia: o combate ao aparato de Estado como poder político separado do corpo social. A noção de máquina de guerra nasce inspirada e desdobrada do conceito de "sociedade sem estado" de Pierre Clastres (1974) ${ }^{3}$. No entanto, afirma como sua melhor efetuação os agenciamentos "bárbaros" dos guerreiros nômades, mais do que os arranjos secretos dos povos "selvagens". Faz parte da estratégia de indestrutibilidade que o segredo do aparecimento intempestivo da máquina de guerra não pertença aos nômades com exclusividade, mas que seja clandestinamente disseminado para certas comunidades em luta, como a literatura: "Um movimento artístico, científico, "ideológico", pode ser uma máquina de guerra potencial, precisamente na medida em que traça um plano de consistência, uma linha de fuga criadora, um espaço liso de deslocamento" (DELEUZE; GUATTARI, 2005a, p. 95).

Dissolução das formas do poder do povo em uma linha abstrata, para que ele nunca possa ser dinamitado. Distração do poder do $\mathrm{Estado}^{4}$, do capital, para que a sua forma totalitária não se instale no lugar do poder-povo. A máquina de guerra distrai a humanidade da própria

\footnotetext{
${ }^{2}$ E com Clarice aprendemos que "a alma é também o corpo" (LISPECTOR, 2004, p. 183).

3 "Estamos de acordo com Clastres quando mostra que uma máquina de guerra está dirigida contra o Estado, seja contra Estados potenciais cuja formação ela conjura de antemão, seja, mais ainda, contra os Estados atuais a cuja destruição se propõe" (DELEUZE; GUATTARI, 2005, p. 16).

${ }^{4}$ Necessário distinguir radicalmente do conceito marxista a noção de Estado que Deleuze e Guattari (2005, p. 16) elaboram a partir da ideia de sociedade sem Estado de Clastres. Ele deve ser compreendido não como a superestrutura de uma base econômica mas, ao contrário, como o grande mecanismo que torna possíveis os processos de produção, os excedentes, a organização das funções públicas e das forças políticas. Enfim, o grande aparelho que "torna possível a distinção entre governantes e governados" e permite o aparecimento do próprio Estado.
} 
guerra. É porque ela não tem como objeto a guerra, mas o movimento das suas linhas de fuga, assim como a literatura tem por objeto de guerra a sua própria ingovernabilidade e também o próprio transbordamento de suas linhas. Perfazendo o seu deslocamento imprevisto e nômade, a máquina nasce de prontidão para combater o aparelho de Estado. E desaparece para reaparecer sem sobreaviso em outros lugares, como os cordões de luzes e tendas, as cidades invisíveis que os ciganos armam e desarmam quando os viajantes passam. Conjurando-o de antemão, sabotando-lhe o espaço de comando, a máquina torna o general inócuo como uma vedete ou um chefe indígena, para que os bandos e os coletivos continuem exercendo o verdadeiro poder, o poder da vida.

Um livro, uma pintura, uma música podem ser máquinas de guerra que só se tornam máquinas de destruição e de morte quando se deixam aparelhar pelo Estado. Então a guerra se torna objeto de sua própria máquina e se volta contra os próprios nômades ${ }^{5}$. Nessa perspectiva de guerreiro se pode, como Clarice Lispector, tomar a escritura como uma antiletratura, posto que, máquina abstrata, ela não cessa de conjurar contra um aparelho que por sua vez só existe para tornar possíveis as instituições e produzir linhas retilíneas e evolutivas (as escolas literárias, as cronologias, as organizações acadêmicas eletivas, as filiações de gênero, as linhas retilíneas e segmentadas de pesquisa) que destroem sua potência de metamorfose ${ }^{6}$. É porque se conecta com outras máquinas abstratas, que produzem não objetos, mas outras engenharias de guerra, capitais intelectuais de transformação e insubordinação que a escrita pode ser vista como máquina.

\begin{abstract}
A escrita e a música podem ser máquinas de guerra. Um agenciamento está tanto mais próximo da máquina abstrata viva quanto mais abre e multiplica as conexões, e traça um plano de consistência com seus quantificadores de intensidade e de consolidação. (DELEUZE; GUATARRI, 2005, p. 202).
\end{abstract}

Esvaziando-a do seu poder sintático e significativo, as máquinas abstratas conectam a literatura com outras máquinas com as quais se tornam inseparavelmente "políticas, econômicas, científicas, artísticas, ecológicas, cósmicas - perceptivas, afetivas, ativas,

\footnotetext{
5 “A máquina de guerra não tem por si mesma a guerra por objeto, mas passa a tê-la, necessariamente, quando se deixa apropriar pelo aparelho de Estado. É nesse ponto muito preciso que a linha de fuga, e a linha vital abstrata que esta efetua, se transformam em linha de morte e de destruição" (DELEUZE; GUATTARI, 2005, p. 202).

6 “'A 'máquina' de guerra (daí seu nome) está, pois, muito mais próxima da máquina abstrata do que, desta está o aparelho de Estado, aparelho que a faz perder sua potência de metamorfose" (DELEUZE; GUATTARI, 2005, p. 202).
} 
pensantes, físicas e semióticas". As conexões fazem a literatura forte e incontrolável. Ela se torna ingovernável. Dissolvendo as formas, fazendo devir-animal, a escritura proclama sua máquina de guerra inumana contra a máquina antropocêntrica que se instala na diegese. Ao tomar o modelo do humano como pressuposto, a máquina antropocêntrica que é, por excelência, de natureza estatal, opera estabelecendo um estado de exceção. Seu mecanismo funciona excluindo o homem como animal mesmo quando o inclui enquanto a espécie que lidera a escalada evolucionista. ${ }^{7}$

Não é por ser abstrata que uma máquina é irreal: do contrário, quanto mais abstrata mais revolucionária ${ }^{8}$. "Nesse caso, escreve-se diretamente com o real de uma matéria não formada, ao mesmo tempo em que essa matéria atravessa e tenciona a linguagem não formal em sua totalidade". (DELEUZE; GUATTARI, 2005, p. 202). O regime das máquinas abstratas não passa mais pelo significante nem pelo subjetivo, mas pelo seu fora, pelo enlouquecimento das formas e dos sujeitos: “A máquina continua escrevendo. Por exemplo, ela vai escrever o seguinte: quem atinge um alto nível de abstração está em fronteira com a loucura. [...]Agora a máquina vai parar. Até sábado próximo" (LISPECTOR, 2004, p. 158). Os criadores se realizam com o próprio ato abstrato da loucura. Assim como a guerra, a loucura é, por caminhos diferentes, tanto uma medida para a saúde quanto para a doença. A obra de arte é um ato de loucura, "só que germina como não-loucura e abre caminho" (LISPECTOR, 2004, p. 171).

Não é o tecido social que engendra o aparelho de Estado, nem o escritor que cria a máquina. É precisamente o contrário. O aparelho de Estado escreve no tecido social sedentário os seus códigos políticos e, no espaço liso literário, a máquina da escrita escreve as linhas de subjetividade abstratas e desviantes que desorganizam os sujeitos estriados. Essa consciência de guerreiro nômade percorre a série "Máquina escrevendo" publicada no jornal: "A máquina corre antes que meus dedos corram. A máquina escreve em mim” (LISPECTOR, 2004, p. 156).

Assumida como "plano de composição consistente" de uma máquina de linhas abstratas, a antiperspectiva literária ou perspectiva do inumano acontece na literatura como uma correnteza forte que tudo arrasta. Tomando o inumano como princípio do processo da

\footnotetext{
${ }^{7}$ A máquina antropocêntrica se define pelo mecanismo de exceção que seleciona os indivíduos aptos e dignos de compor o modelo de humano, conforme Agamben (2006). Esse mecanismo regular constrói os indivíduos eleitos opondo-os ao animal e ao outro inumano que ela produz no seio do homem: os negros, os índios, as mulheres, as crianças, os loucos, os selvagens, os insubordinados etc., entre os quais produz uma associação inferiorizante. Opera-se aí um paradoxo: o corpo dos que servem de contra modelo é capturado só para ser excluído, ou seja, a inclusão é sempre da ordem da exclusão.

8 "Um devir-animal como os camundongos de Kafka, os ratos de Hofmannsthal, os bezerros de Moritz? Uma máquina revolucionária, tanto mais abstrata quanto é real” (DELEUZE; GUATTARI, 2005, p. 201).
} 
linguagem, o plano de composição não guarda um sentido temático, alegórico ou metafórico, mas atua como modo de tocar a matéria e a linguagem da arte em sua fluidez. Ocorre um desfazimento das palavras e significados em favor de uma gramática das criaturas e objetos que têm o seu próprio "halo", a sua própria resistência e devir. Essa gramática insubordinada do devir não cessa de fazer o autor e a própria escritura perderem sua centralidade. O princípio da inumanidade da linguagem impacta a literatura, a ponto de reinventar a ideia de obra, de gênero, de narrativa, de personagem e da própria autoria.

O "Plano de composição" se contrapõe ao "plano de organização" ou de desenvolvimento que estrutura as obras de arte regidas pelo princípio da transcendência, conforme proposto por Deleuze e Guattari (1997, p. 75). Ao segundo plano se associam as narrativas onde formas e sujeitos se desdobram em direção a um desfecho programado dentro de uma arquitetura suplementar à própria obra. Do contrário, o plano de composição ou de consistência é regido pelo princípio da imanência e da univocidade. Ele faz a escritura deslizar e crescer por velocidades e intensidades, pelo devir imprevisível de acontecimentos e não pela sequência de desdobramentos. "Por mais que cresça em dimensões jamais terá uma dimensão suplementar àquilo que se passa nele” (DELEUZE; GUATTARI, 1997, p. 55).

No plano liso dos devires (do ser-texto), no qual o inumano é já o próprio "princípio de composição", A paixão segundo G.H. e Água Viva colocam a funcionar um modo de antirromance ou de antiliteratura que liberta por natural insurgência a literatura da instituição literária e o romance da instituição romance. Objeto gritante, primeira versão de Água Viva, manifestava essa luta de um "ar natural desafiador": "É só por heroísmo também que publico este livro que vai ser vaiado e cujas intenções de antiliteratura serão captadas por poucos" (LISPECTOR, apud RONCADOR, 2002, p. 49). Intencionalidades, posicionamentos que estavam dados também em "O relatório da coisa": "O meu jogo é aberto: digo logo o que tenho a dizer e sem literatura. Este relatório é a antiliteratura da coisa” (LISPECTOR, 1999a, p. 103).

Involução das formas, transubstancialização da matéria, desestruturação do enredo, da lógica retilínea, da história, do personagem, do narrador, do tempo, do gênero e do pensamento para ir "atrás do que está atrás" (LISPECTOR, 1998a, p. 13). Desagregação de todos esses elementos que ajudam a operar a centralidade do homem na narrativa em favor do fluxo da escrita, escorregando livre no espaço literário para reencontrar essa intensidade de halo na multiplicidade escrevente. "A criação me escapa" (LISPECTOR, 1998a, p. 66). Uma literatura assim - onde já não se separam a narrativa e o ensaio, o texto e a obra, o fundo e a forma alcança o próprio gesto da loucura, pois independe da história, da mesma forma que uma pintura 
está livre da figura. Ela se escreve numa "língua que não é mais a das palavras, numa matéria que não é mais a das formas, numa afectibilidade que não é mais a dos sujeitos" (DELEUZE; GUATTARRI, 1997, p. 44).

Essa literatura que não conhece a Lei, é a do devir. Desde sempre grávida das relações promíscuas entre escrita e inumanidade, ela só conhece a transformação do ser e da obra. Nos platôs de Capitalismo e Esquizofrenia, o inumano aparece no devir que compartilhamos com a zoologia e com a botânica. Fazer rizoma é percorrer linhas imperceptíveis de escape e de retorno para as multiplicidades animais e vegetais. É fazer uma cartografia em comum com ratos, formigas, orquídeas, ervas daninhas... Com eles o humano tem semelhanças que nos tornam distintos e complexos onde somos moleculares e impessoais.

É uma questão de saber se a botânica, em sua especificidade, não seria inteiramente rizomórfica. Até animais o são, sob sua forma matilha; ratos são rizomas. As tocas o são, com todas suas funções de hábitat, de provisão, de deslocamento, de evasão e de ruptura (DELEUZE; GUATTARI, 1995, p. 15).

Em uma frase no infinitivo, gravada, pois, na ausência de sujeito, A paixão segundo G.H. oferece o que talvez seja a definição mais breve e aberta de inumano: "Estar vivo é inumano." (1998b, p. 171). O inumano entra em curso como voz narrativa e como linguagem do devir que se descobre no processo da escritura. Sua bandeira política: a liberdade de escrita e de pensamento. "Construo algo isento de mim e de ti - eis a minha liberdade" (LISPECTOR, 1998a, p. 17).

No plano de composição, os elementos da escrita não param de fazer e desfazer agenciamentos. Por isso, ele se opõe ao princípio do desenvolvimento evolutivo, que procede por filiação a formas, em favor de um plano de proliferação por involução e recuo, onde a forma não para de ser dissolvida para liberar tempos e velocidades. Um plano de composição faz a narrativa deslizar nesses textos como corpo sem órgãos, no modo de um pensamento da liberdade. A máquina da escrita bombeia o sangue pelos ossos, liberando o corpo-texto dos órgãos que entopem a engrenagem com a Ideia do humano para restituir-se em puro fluxo e pensamento.

É assim certa espécie de pensar-sentir que chamarei de 'liberdade', só para lhe dar um nome. Liberdade mesmo - enquanto ato de percepção - não tem forma. E como o verdadeiro pensamento se pensa a si mesmo, essa espécie de 
pensamento atinge seu objetivo no próprio ato de pensar (LISPECTOR, 1998a, p. 89).

Vocação involutiva da escrita, que faz do poeta verdadeiramente um "ladrão de fogo", um fogo inventor e alheio, como escreve Rimbaud em uma "prosa sobre o futuro da poesia", dirigida a Paul Demeny, em Carta do Vidente (2005). "Se o que traz de longe tem forma, ele dá forma; se é informe, dá algo de informe". Ao lidar com a coisa informe, o poeta incorpora esse além-do-homem. "Ele é encarregado da humanidade, dos próprios animais". Para superar a forma terá que devir até a poeira, até o código do silício, ou como continua a carta, "deverá fazer sentir, apalpar, escutar as suas invenções” (RIMBAUD, 2005, p. 82).

Em Le différend (1983), seu estudo sobre um intradutível diferendo ${ }^{9}$, Lyotard afirma que o sentido de inumano é mesmo incompatível com a Ideia de humanidade. A contundência dessa afirmação nos diz que a Ideia convoca um modo de frase no qual o pensamento antropocêntrico se constitui e opera. Para vingar a Ideia, o modelo do que é justo, verdadeiro, bom, belo, correto, humano por fim, se instala no encadeamento lógico da linguagem. Em um ensaio sobre os modos de se interrogar o inumano na obra de Lyotard, o filósofo José António Domingues lembra que a ideia de humanidade se estabelece excetuando as linhas de expressão que escapam ao modo de funcionamento da frase. "Para indagar as propriedades desta entidade humana pressupõe-se uma linguagem que serve de meio aos fins do pensamento" (DOMINGUES, 2005, p. 2).

Uma sintaxe ideal se cristaliza desde a formulação do pensar, no âmago da linguagem. E se estabelece criando "uma relação de instrumentalidade entre os pensamentos e a linguagem", como mostrou Lyotard (1983, §31). Conexão imediata com aquela queixa do narrador de Rua de Mão Única sobre a monotonia dos diálogos modernos: "É como se estivesse aprisionado em um teatro e se fosse obrigado a seguir a peça que está no palco, queira-se ou não, obrigado a fazer dela sempre de novo, queira-se ou não, objeto do pensamento e da fala" (BENJAMIN, 1987, p. 21). O eixo sintagmático desse teatro pressupõe uma entidade humana no centro da oração a quem a psicologia, a filosofia da linguagem, a sociologia, a psicologia, as ciências humanas, enfim, se dirigem para interrogar: quem enuncia, quem é enunciado, quem fala ou quem pratica a ação?

\footnotetext{
${ }^{9}$ Todo diferente tornado impossível pela linguagem do humano.
} 
Assim a Ideia fica de posse de uma ontologia da linguagem para legitimar o bom julgamento (o bom encadeamento) e o bom pensamento, mas, de facto, como uma só regra universal de julgamento, pois o encadeamento é levado a cabo por si, é um encadeamento decidido em si (DOMINGUES, 2005, p. 3).

Como escapar à armadilha da instrumentalização do pensamento dirigido pelo nexo do humano na linguagem? Como emancipar-se da razão e dar o testemunho do que escapa à Ideia se o inumano é como um locutor recusado e aspirado nesse pensamento? Como criar essa língua da resistência?

Para início de resposta, uma escrita atraída pela resistência do inumano deveria ser constituinte do objeto que a constitui. Isso implica considerar até a raiz que o humano e o inumano operam, como nos mostra Lyotard, linhas de expressão bem distintas desde a sua formulação. Conhece-se bem a sintaxe da primeira: pessoa, sujeito, verbo, predicado, complemento. Formam um caminho tão previsível quanto essa rua de mão única de que reclama Benjamin, onde o sujeito, dono da ação/verbo, precisa ser localizado para que o objeto, nome da coisa que sofre a ação, seja rapidamente também identificado e hierarquicamente posicionado. Quanto à sintaxe da linha de expressão do inumano, nada se sabe, além de que há uma voz intradutível em palavras e no modo de encadeamento humano.

Um devir minoritário e resistente da escrita parece estar naquele modo antigramatical que começa por suspender o império do sujeito utilizando as próprias armadilhas da língua contra a sintaxe da Ideia. Fala-se em trazer um pronome neutro para esvaziar o centro da frase, fazendo-o operar não como índice de diferenciação entre a coisa e o sujeito, mas como dispositivo de dessubjetivação. Fala-se também dessa partícula de indeterminação do sujeito no verbo e também da estrutura nominal do infinitivo, que colocam a ação no lugar de quem fala. Fala-se de todos os outros modos já inventados, e que faltam à linguagem, de ausentar, esfacelar ou multiplicar o sujeito da Ideia. "Arrisco? deixo eu sentir?, perguntava-se nela. Sim, respondeu-se por mim” (LISPECTOR, 1999b, p. 96).

A mudança molecular da sintaxe ainda está por vir. Requer colocar intensamente em ação o ferramental descentralizador do eu na escrita e propor modos frasais não gramaticais, correspondentes a ideações menos restritivas e narcísicas. Implantar na língua portuguesa - por apropriação das mais antropofágicas - um pronome neutro e estrangeiro. Com Água viva, o it tornou-se uma materialização singular do lugar neutro onde a possibilidade/fracasso de funcionamento do inumano na escritura pode acontecer. 
Sou-me. Mas há também o mistério do impessoal que é o "it": eu tenho o impessoal dentro de mim e não é corrupto e apodrecível pelo pessoal que às vezes me encharca: mas seco-me ao sol e sou um impessoal de caroço seco e germinativo. Meu pessoal é húmus na terra e vive do apodrecimento. Meu "it" é duro como uma pedra-seixo. (LISPECTOR, 1998a, p. 30).

Na literatura, o inumano não é exceção, nem regra. Alcançá-lo: condição para que a escritura comece e atinja liberdade e saúde em sua plenitude. Em um sentido mais agudo, o inumano só acontece na linguagem pelo paradoxo de um eu-it, a voz neutra que concebe Água viva ou a "massa branca" que escreve A paixão segundo G.H. Instaurando nessas escrituras uma perspectiva estética não-antropocêntrica no neutro da autoria, o it é o próprio "halo" de criação, esse canto que transcende a origem das frases e das palavras e ao mesmo tempo é imanente ao mundo, se a gente mergulha na linguagem clariceana:

O que te escrevo não tem começo: é uma continuação. Das palavras deste canto que é meu e teu, evola-se um halo que transcende as frases, você sente? Minha experiência vem de que eu já consegui pintar o halo das coisas. O halo é mais importante que as coisas e as palavras. O halo é vertiginoso. Finco a palavra no vazio descampado: é uma palavra como fino bloco monolítico que projeta sombra. E é trombeta que anuncia. O halo é it. (LISPECTOR,1998a, 48).

No espaço literário, a relação entre as diferenças se produz por esmagamento mútuo, como o que ocorre com G.H. e a barata. A massa branca é o produto mais refinado desse contato humano-animal. Matéria neutra, zona de entremeio onde a diferença se dissolve e onde os corpos compartilham um "ser-em-comum", para referenciar Nancy (2006). Partidas as cascas, os interiores esmagados transbordam para o fora e se misturam. No abandono de todo recurso de individualização dos personagens, a escritura procede um descarnamento da pessoa para que o núcleo se exteriorize, como analisa Florencia Garramuño (2011, p. 109-110): "Mais do que uma despersonalização, trata-se de alcançar o impessoal, despojando o pessoal de toda distinção particularizante, de todo dado identificador." O escritor e o personagem somente se afirmam em nome de uma ausência. Todo sujeito, se existe, pressupõe uma presença "por inércia", conforme Garramuño (2011, p. 108). 
Tal escritura se afirma reconhecendo a si mesma como um lugar de anonimato onde o eu só pode se enunciar como uma "pessoa primitiva", que coloca a funcionar uma autoria it: "Na hora de pintar ou escrever sou anônima. Meu profundo anonimato nunca ninguém tocou" (LISPECTOR, 1998a, p. 34). Deleuze e Guattari (1997, p. 53) fizeram o elogio ao neutro da língua, afirmando a assertiva de Blanchot (1987) de que o on e o $i l$ em francês (assim como o se em português) não substituem o lugar do sujeito mas, do contrário, o destituem em proveito de um agenciamento universal ${ }^{10}$. Mas nem Deleuze e Guattari, nem Blanchot imaginaram um artifício de linguagem tão menor, e tão menos institucionalizado dentro da própria língua quanto o it que Clarice Lispector cavou dentro da língua portuguesa.

Em Água viva, esse pronome intruso e estrangeiro destitui o autor do poder de dizer eu para que a literatura se afirme como um caso de impessoalidade. No lugar de contato criado pela pronominalidade neutra do it, o ponto de vista do eu se dissolve. É porque ele cria também um lugar neutro para a alternância do ponto de vista de todos os seres e de todas as coisas num universo que só conhece individuações provisórias e hibridizadas.

Uma escritora que devém-mulher avança sobre o que historicamente se concebeu como domínios literários do masculino. E inventa o feminino, libertando a escritura dos papéis institucionalizados e domesticados de gênero, mas buscando sofregamente "o que está atrás" da dicotomia de gêneros. Na galeria e trânsito das metamorfoses, a classificação estável dos protagonistas como corpos masculinos ou femininos, humanos ou animais fica perturbada pelo hibridismo e pela indefinição de seres que não são feitos à imagem e semelhança de um autordeus tautológico. Atrás dos gêneros literários e humanos, um corpo femino se deixa interpelar por um corpo animal, sob cujo impacto adentra o espaço oco de uma pluralidade inclassificável. Em Água Viva, esse corpo vai mesmo se esfacelando, se transmutando e se multiplicando à medida que transita por uma rede de seres e objetos da maior heterogeneidade - flor, animal, água, objeto.

A assinatura Clarice Lispector espraia sua fauna nos mais diversos textos, constituindo uma verdadeira zoografia, termo que em grego designava a "pintura do vivo". Nisso, o tornar-se-homem passa necessariamente por um tornar-se mulher, tornar-se animal, tornar-se-cão antes de todos, tornar-se galinha, tornar-se galo, tornar-se búfalo etc. (NASCIMENTO In: MACIEL, 2011, p. 143).

${ }^{10}$ Dizem os autores ainda: "O $I L$ não representa um sujeito, mas diagramatiza um agenciamento. Ele não sobrecodifica os enunciados, não os transcende como as duas primeiras pessoas, mas, ao contrário, os impede de cair sob a tirania das constelações significantes ou subjetivas" (DELEUZE; GUATTARI, 1997, p. 53). 
Para os seres de fabulação, que não estão fundidos à centralidade e identidade do autor, que têm vida própria e autonomia porque são feitos de "linhas vivas", "linhas de carne", como dizem Deleuze e Guattari (1996, p. 66), o mundo inteiro é inumano. O mar líquido contra o corpo de mulher compacto. "Ela e o mar". Quando o "e" opera uma conexão, não uma dicotomia, já não se sabe mais o que é sujeito, quem é objeto, assim como o feminino e o masculino não produzem também nenhuma hierarquia ou fixidez. É pura alternância de posições: “Às vezes o mar lhe opõe resistência puxando-a com força para trás, mas então a proa da mulher avança um pouco mais dura e áspera” (LISPECTOR, 1999a, p. 90).

$\mathrm{Na}$ forma inclassificável dessa literatura, inscrevem-se a multiplicidade e a indecibilidade do próprio ser. Como a água, que é só um fluxo e um escoar contínuo, a obra viva abraça todas as possibilidades sem se fixar ou se esgotar em nenhuma forma. Conto, crônica, comentário, ensaio, novela, romance, texto? Fluxo, fluxo, sangue, sangue, corpo sem órgãos! "Mistério", já insistia a escritora nos textos para o Jornal do Brasil. "Vamos falar a verdade: isso aqui não é crônica coisa nenhuma. Isto é apenas. Gêneros não me interessam mais. Interessa-me o mistério" (LISPECTOR, 2004, p. 157).

Máquina de guerra contra as separações que bloqueiam a potência das metamorfoses, a literatura está predisposta a formar uma comunidade sem regulações políticas ou morais da vida coletiva que nela pulsa. Por imanência ela se insurge contra a máquina estatal e as biopolíticas implodindo a soberania das identidades com a ética dos devires. O embate entre as máquinas vem para o espaço literário como expressão da luta entre a abertura do devir-inumano, típico da escritura, e o fechamento próprio do porvir-humanista sobre o mundo e os seres.

Laboratório de construção de "hecceidades" e desconstrução de identidades, máquina de devires, a potência da literatura não se contém como conteúdo da ideação antropocêntrica. Hecceidades são "um modo de individuação que não se confunde com o de uma coisa ou de um sujeito", dizem DELEUZE e GUATTARI (1997, p. 47). São uma pronominalidade neutra, de onde derivam singularidades universais, pontuadas por artigos indefinidos que desabilitam toda ordem de definição identitária e pessoal: “A mulher é agora uma compacta e uma leve e uma aguda" (LISPECTOR, 1999a, p. 89).

Em Perto do coração selvagem, essa literatura já se descobria como potência do indefinitivo, capaz de produzir individuações indissolúveis entre um ser e qualquer outro ser, mas também entre um ser e uma entidade meteorológica, um acidente geográfico, um tempo, qualquer coisa. Operação que consiste em fazer um ou mais termos recuarem de suas formas 
próprias em favor de uma indefinição onde eles se compartilham e se modificam. Desde Joanamenina diante do mar ela descobrira esse "poder-de-vida" que transborda na escritura: "A paz que vinha dos olhos do boi, a paz que vinha do corpo deitado do mar, do ventre profundo do mar, do gato endurecido sobre a calçada. Tudo é um, tudo é um...” (LISPECTOR, 1986, p. 4748). Desde Joana-menina, essa literatura soube que "a confusão estava no entrelaçamento do mar, do gato, do boi com ela mesma", embora não soubesse "se entrara no tudo é um ainda em pequena, diante do mar, ou depois, relembrando", pelos artifícios da linguagem e da memória. Mas isso também já não tem nenhuma importância: as hecceidades hibridizam e individuam a linguagem e a lembrança na própria vida.

Hecceidades se reconhecem também em conjuntos, em blocos, mesmo precedidas de artigos definidos que só estão diante delas para disfarçar uma impessoalidade. Individuações sem sujeito, singularidade do universal pela qual elementos distintos entram em devir. Modos de sintaxe em que o pronome - masculino ou feminino, singular ou plural, superlativo ou diminutivo - entra em devir com o outro e toma a indefinição do híbrido e a multidão do corpo. Arte de esgarçamento da linguagem, das classificações de gênero, número e grau na qual essa escritura tem maestria: "Eu me sentia como se algo meu nos visse de longe - Assim: 'A moça e o cavalo", confundindo-se em uma "adolescência de menina-potro" (LISPECTOR, 1999a, p. 37).

É o mesmo arrebatamento de corpos que suspende todas as determinações de sujeito. É o mesmo amor impessoal atravessando o devir-povo da cantora-camundongo, em "Josefina, a cantora ou o povo dos ratos", de Kafka. Uma artista capaz de falar em nome dos animais com sua arte e sua voz: "Mas para um povo com tal estado de ânimo, Josefina traz ainda mais" (KAFKA, 1989, p. 122). "A moça e o cavalo", "Ela e o mar”, “A artista e o povo”. Feitiçaria da máquina da escrita: de tanto levar a linguagem ao seu limite, a literatura faz o pronome "a" ou "o"; "ela" ou "ele" devir um povo, uma infância, uma coragem, uma mocidade, uma adolescência, uma animalidade, uma mulheridade.

Com Lévinas (2010) podemos dizer: ele e ela são eleidade; tu é outridade; nós, comunidade. Com Deleuze (1997) podemos dizer que eu e todos somos também hecceidades. Feitiçaria de escritor-xamã que transforma a "literatura como um caso imediatamente universal", mesmo quando biográfica ou autobiográfica. A escritura arranca o eu da pessoalidade e o faz ecce (eis aqui), uma individuação do agora. Seja o "eu" um autor, um narrador ou um personagem, não importa se ela diga "eu” ou "nós”, uma presença na escritura 
não nomeia uma identidade, mas uma singularidade conectada com uma cosmogonia, como nos mitos indígenas.

Desinventando-se a sintaxe do humano pode-se pensar em um encadeamento inumano, onde o animal, a máquina, o vegetal ou o impessoal operem também como linguagem. Se literatura se produz forçando os limites que separam a linguagem da animalidade, que separam a palavra da voz animal, um escritor escreve pelos povos que morrem para a linguagem humanista mas não para a escritura do limite. Voltando então àquela enigmática emblemática frase de Mil Platôs, que sentidos se pode derivar deste dizer? "O escritor é um feiticeiro, pois vive o animal como a única população frente à qual ele é responsável de direito" (DELEUZE; GUATTARI, 1997, p. 21). No território de quebra de limites da literatura, escritores se encontram com o animal diante da tarefa de trazer do esquecimento as vozes que estão morrendo para a linguagem e para a Ideia do Homem. A língua dos animais, das crianças, dos loucos, dos iletradados, dos povos menores, dos que desaparecem do mundo sem testemunho, dos que não repetem modelos e padrões de linguagem.

Ser responsável pelos animais não quer dizer escrever para eles lerem, tampouco escrever no lugar deles, explica Deleuze no seu L'Abécédaire (1996), mas escrever em intenção deles, levando a linguagem aos limites que separam o homem da animalidade de um modo que não se fique mais separado dela. "Só há literatura quando se leva a linguagem a esse limite". E fazendo jus à herança de Nietzsche em Assim falava Zaratustra (2011), lembrar que há uma inumanidade própria ao corpo humano e ao espírito humano que pode mover as relações animais da escrita com o animal. Assim como há uma animalidade própria ao corpo da linguagem, com a qual Clarice nos conectou desde o primeiro romance, Perto do coração selvagem:

Sentia dentro de si um animal perfeito, cheio de inconsequências, de egoísmo e vitalidade. [...] Sim, ela sentia dentro de si um animal perfeito. Repugnavalhe deixar um dia esse animal solto. Por medo talvez da falta de estética. Ou receio de alguma revelação... Não, não, — repetia-se ela — é preciso não ter medo de criar. (LISPECTOR, 1986, 17-18).

Escrever o inumano não é escrever sobre animais, mas fazer operar na escrita um animal. “E se nos tornássemos animal ou vegetal por literatura?", perguntam Deleuze e Guattari. "Não seria primeiramente pela voz que alguém se torna animal?" (1995a, p. 12). Um escritor não escreve para leitores previsíveis que vão se reconhecer nas linhas de um romance ou de uma 
novela, mas para arrancar da letra povos secretos, seres de fronteira, de não-escrita, de nãolinguagem, experiências ofegantes como a de Ofélia e o pinto que a escrita prenuncia em seu silêncio ritualístico.

Como quem está “sozinha na noite de outra pessoa” (LISPECTOR, 1999b, p. 89), uma escritora escreve para convocar a voz de uma coruja, de uma barata, de um cavalo, de uma criança que se cala. Para ecoar o silêncio de um pinto que ela adivinha caído no chão da cozinha, no intervalo entre a intuição e a revelação, antes de afastar pesadamente as cadeiras no caminho, ao sabor do azar e dos acidentes da linguagem, guiada pela mudez e pelo olhar mortificado de uma menina que acabara de celebrar com o diminuto e ensolarado ser o reacontecimento da infância, ainda com o cheiro recente do novo. É aí que ela se instaura, para alcançar essa infância na sua "distância infinita", para tentar salvá-la e curá-la, antes que se vá de todo, congelada pelo medo e pela culpa. Então a escrita fala a essa criança, sussurrando ao seu ouvido com a doçura da oralidade, com a coragem de verdade de quem conhece a palavra, não a mentira: "Oh, não se assuste muito! Às vezes a gente mata por amor, mas juro que um dia a gente esquece" (LISPECTOR, 1999b, p. 100).

Escrever o inumano é convocar um autor que escreve rasgando a sintaxe como um animal, cavando um mundo dentro de outro, como o carrapato rasga sua sintaxe de vida no território corpóreo do boi. E se a gente pensa a escritura e a vida desse modo inseparável, como faz Deleuze em L'Abécédaire (1996), quem disse que os animais não criam um mundo? Escrever como um animal é inventar uma nova língua dentro de outra, onde o mundo "há" apenas, sem subordinação ao sujeito da frase. "Eu que não me lembrava de lhe avisar que sem o medo havia o mundo" (LISPECTOR, 1999b, p. 100). É fazer operar na escrita essa multiplicidade de seres, de povos, de rumores e de dizeres que desaparecem para a linguagem. Nesse sentido, escrita é túmulo de devires - paradoxo pelo qual ela dá o testemunho do silêncio que permanece vivo na língua morta. "Embaixo da mesa, estremece o pinto de hoje. O amarelo é o mesmo, o bico é o mesmo. Como na Páscoa nos é prometido, em dezembro ele volta" (LISPECTOR, 1999b, p. 100).

Uma escrita animal se produz no modo de insubordinação do encadeamento frásico, no esgarçamento de fronteiras até o limite que a separa de outros territórios, de outros reinos, do não-eu, da não-linguagem ou do não-pensamento. Conciliação não é a tarefa da filosofia, não é a tarefa do pensamento, nem da escritura, diz finalmente Lyotard (1989) em Témoigner du 
différend; quand phraser ne se peut ${ }^{11}$. A violência da linguagem acontece em nome da resistência do inumano. Escrever como um animal é fazer da escrita, esse dispositivo de exceção, de separação entre letrados e iletrados, um estado de graça.

Sistema de poder é controle e doença, literatura é delírio e saúde, diz Deleuze. E como delírio, não produz pactos familiares ou privados; ao contrário, promove alianças entre informes, matilhas heterogêneas que fazem linha de fuga. A literatura das minorias produz "formação delirante histórico-mundial" e levanta minorias nas "zonas femininas da História". Por isso o escritor é uma mulher, um negro, uma criança, uma coruja, um cavalo, um estudante, um povo menor. Por isso o poeta grita, como Rimbaud (2005, p. 82): "Sou um animal, um negro...”. Mas se o poeta é "o homem carregado de seus próprios animais", como na leitura de Deleuze do super-homem ${ }^{12}$, esse pensamento pode nos levar ainda mais longe no ofício de crítica e nos fazer acreditar que, ao fundo, os animais carregam o poeta. Só resta então, dedicar a eles a autoria, como fez Derrida com o poema-ouriço (2001, p. 113). Não é o autor, não é o sujeito, não é decididamente o eu quem escreve o animal. Ele, como o outro, leitor ou iletrado, se expõe animal autobiográfico (DERRIDA, 2002). Cada presença no mundo é uma escritura, uma biografia que se conta.

A esta altura podemos dizer: escrever é inumano, é percorrer linhas que escapam e transbordam para todos os lados. Para o ser desorganizado pelas linhas de fuga da escritura, escrever é fazer operar um inconsciente coletivo e inumano. É trazer de volta para a literatura povos que morrem e "Temas que morrem" para o humano, como o "estado de graça".

Constituída na pura experimentação do devir, literatura é potencialmente um lugar onde se pode operar um pensamento, uma estética e uma escrita do inumano, devolvendo a posse da linguagem ao mundo. Mais do que um objeto extraliterário, o animal se coloca como uma potência que reanima e reanimaliza a narrativa revendo a relação ética e estética do homem com o corpo-mundo que ele coabita. Não se reconciliará com a máquina estatal, com a máquina antropocêntrica. "Reconciliar-se com o mundo", dirá Francis Ponge (1997, p. 69). O homem se reconcilia com o mundo inumano quando se dispõe a aprender com ele, do mesmo modo que o

\footnotetext{
11 "Testemunho do différend: quando não se pode frasear». Escreve Lyotard: «Nous avons bien assez de violence avec la pensée. Donc, en ce second sens, on peut parler de conciliation. Mais elle n'est pas la tâche de la philosophie en tant que pensée et écriture". Tradução nossa: "Nós temos violência o bastante com o pensamento. Então, nesse segundo sentido, podemos falar de conciliação. Mas ela não é a tarefa da filosofia enquanto pensamento e escritura". (1989, p. 119).

12 O super-homem é, segundo a fórmula de Rimbaud, o homem carregado dos próprios animais (um código que pode capturar fragmentos de outros códigos, como nos novos esquemas de evolução lateral ou retrógrada). É o homem carregado das próprias rochas, ou do inorgânico (lá onde reina o silício) (DELEUZE, 1988, p. 141-2).
} 
poeta se reconcilia com a natureza muda da escrita. "Quero escrever-te como quem aprende" (LISPECTOR, 1998a, p. 14).

As linhas da literatura não se separam das linhas da vida, segundo a lição fundamental que nos deixou a escrita do "nós" (DELEUZE; GUATTARI, 1996). Ultrapassando até o limite a fratura que separa os viventes, a máquina literária combate a máquina antropocêntrica. É porque as aproximações ontológicas e estéticas que ela promove entre as fronteiras são anarquizantes e procuram as revoluções. É porque, enfim, a literatura perfaz esse eterno retorno ao mito da indiscernibilidade e da comunicabilidade entre os seres, as coisas e o mundo que compõe, em última análise, a sua visão do escuro e a sua voz do silêncio.

Procurar o pensamento anterior, o ser, e o dizer que estão atrás do olhar, atrás do pensamento, atrás do sujeito e atrás da escrita. Afastar-se da Lógica para encontrar o infinito de lógicas e de sensibilidades. Emperrar, enguiçar a máquina antropocêntrica, a máquina do Estado. Jogar areia no motor, se não se pode pará-la. Talvez, dessa forma, seja possível chegar, pela máquina da escrita, ao que importa, à matéria-prima do livre-pensar tendo-se atingido o livre-escrever. E nessa liberdade, que ainda não foi longe no recuo do eu, contrapor a sintaxe da premissa "Penso, logo existo", no modo cartesiano e antropocêntrico, à do "Existe, logo pensa", no modo do perspectivismo ameríndio proposto por Viveiros de Castro (2012). Mas ainda não se terá ido muito longe, e por que não dizer, então, nos rastros de um animal escrevente: Existe, resiste, logo escreve!

P.S.: Estou solidária, de corpo e alma, com a tragédia dos estudantes do Brasil feridos na Universidade Federal de Santa Catarina.

\section{REFERENCIAS}

AGAMBEN, Giorgio. Lo abierto: el hombre y el animal. Tradução de Flávia Costa, Edgardo Castro. Buenos Aires: Adriana Hidalgo Editora, 2006.

O que é um dispositivo? In: AGAMBEN, Giorgio. O que é o contemporâneo e outros ensaios. Tradução Vinícius Nikasto Honesko. Chapecó: Argos, 2009. p. 25-58.

BENJAMIN, Walter. Rua de mão única. Tradução de Rubens Rodriguez Torres Filho e José Carlos Martines Barbosa. São Paulo: Brasiliense, 1987. (Obras escolhidas, v. II).

BLANCHOT, Maurice. O espaço literário. Tradução de A. Cabral. Rio de Janeiro: Rocco, 1987.

CLASTRES, Pierre. Sociedade contra o estado. Tradução de Theo Santiago. Rio de Janeiro: Editora Francisco Alves, 1974. 
DELEUZE, Gilles. L'Abécédaire de Gilles Deleuze: documentário com Gilles Deleuze. Direção: Pierre-André Boutang. Produção: Sodaperaga; La Femis. 450 min. França, 1996. Disponível em: <//http://vimeo.com/10192065> Acesso em: 04 jul. 2013.

Crítica e clínica. Tradução Peter Pál Pelbart. Rio de Janeiro: Editora 34, 1997.

DELEUZE, Gilles; GUATTARI, Felix. Kafka: por uma literatura menor. Tradução de Júlio Castañon Guimarães. Rio de Janeiro: Imago, 1977.

. Mil Platôs: capitalismo e esquizofrenia. Tradução de Aurélio Guerra Neto e Célia Pinto Costa. Rio de Janeiro: Editora 34, 1995. v.1.

. Mil Platôs: capitalismo e esquizofrenia. Tradução de Aurélio Guerra Neto, Ana Lúcia de Oliveira, Lúcia Cláudia Leão e Suely Rolnik. Rio de Janeiro: Editora 34, 1996. v. 3.

. Mil Platôs: capitalismo e esquizofrenia. Tradução de Suely Rolnik. Rio de janeiro: Editora 34, 1997. v. 4.

. Mil Platôs: capitalismo e esquizofrenia. Tradução de Peter Pál Pelbart e Janice Caiafa. Rio de Janeiro: Editora 34, 2005. v. 5.

DERRIDA, Jacques. Che cos 'é la poesia?, Tradução. Tatiana Rios e Marcos Siscar. In: Inimigo Rumor, $\mathrm{n}^{\circ}$ 10, Rio de Janeiro: 7 Letras, maio, 2001, p. 111-115.

. O animal que logo sou. São Paulo: Editora Unesp, 2002.

DOMINGUES, José António. Por que o inumano? Portugal: LusoSofia Press, 2005.

Comunicação ao Congresso Internacional da Associação Portuguesa de Filosofia

Fenomenológica (AFFEN) em Coimbra, março 1005. Disponível em:

$<$ http://www.lusosofia.net/textos/domingues_jose_porque_inumano.pdf $>$ Acesso em: $28 \mathrm{mar}$. 2005.

FOUCAULT, Michel. Poder e saber. In: Estratégia, Poder-Saber. Org. Manoel Barros da Motta. Tradução de Vera Lúcia Avelar Ribeiro. Rio de Janeiro: Forense Universitária, 2010b, p. 223-240. (Coleção Ditos \& Escritos IV).

GARRAMUÑO, Florencia. Região compartilhada: dobras do animal-humano. In: MACIEL, Maria Esther (Org.). Pensar/escrever o animal. Florianópolis: UFSC, 2011. p. 105-116.

KAFKA, Franz. Nas galerias. Tradução Flávio R. Kothe. São Paulo: Estação da Liberdade, 1989.

LÉVINAS, Emmanuel. Entre nós: ensaios sobre a alteridade. Petrópolis: Vozes, 2010.

LISPECTOR, Clarice. Perto do coração selvagem. Rio de Janeiro: Nova Fronteira, 1986. . Água viva. Rio de Janeiro: Rocco, 1998a.

. A paixão segundo G. H.. Rio de Janeiro: Rocco, 1998b.

. Onde estivestes de noite? Rio de Janeiro: Rocco, 1999a.

. A legião estrangeira. Rio de Janeiro: Rocco, 1999b.

. Aprendendo a viver. Rio de Janeiro: Rocco, 2004.

LYOTARD, Jean-François. Le différend. Paris: Les Éditions de Minuit, 1983.

Témoigner du différend: quand phraser ne se peut. Paris: Editions Osiris, 1989.

NANCY, Jean-Luc. Ser singular plural. Tradução de Antonio Tudela Sancho. Madrid: Arena Libros, 2006. 
NASCIMENTO, Evando. Rastros do animal: a ficção de Clarice Lispector. In: MACIEL, Maria Esther (Org.). Pensar/escrever o animal: ensaios de zoopoética e biopolítica. Florianópolis: UFSC, 2011 a.

NIETZSCHE, Friedrich. Assim falava Zaratustra: um livro para todos e para ninguém. Petrópolis: Vozes, 2011.

PONGE, Francis. Métodos. Tradução de Leda Tenório da Motta. Rio de Janeiro: Imago, 1997.

RIMBAUD, Arthur. Uma estadia no inferno; Poemas escolhidos e A carta do vidente. Tradução e organização de Daniel Fresnot. São Paulo: Martin Claret, 2005.

RONCADOR, Sônia. Poéticas do empobrecimento; a escrita derradeira de Clarice. São Paulo: Annablume, 2002.

VIVEIROS DE CASTRO, Eduardo. A inconstância da alma selvagem; e outros ensaios de antropologia. São Paulo: Cosac Naify, 2011.

. "Transformação" na antropologia, transformação da "antropologia”. In: Mana. vol.18 n.1 Rio de Janeiro, abril 2012, p. 1-10, disponível em: <http://www.scielo.br/scielo.php?pid=S0104-93132012000100006\&script=sci_arttext. $>$ Acesso: 30 de junho de 2013. 